\title{
Magnanimous leadership: Edmund Barton and the Australian founding*
}

\author{
Haig Patapan \\ Griffith University, Brisbane, Queensland, Australia
}

\begin{abstract}
This article explores the nature of leadership that is needed in democratic transitions. It argues that the conventional scholarship on democratisation, and the leadership scholarship on transformative and transactional leaders, needs to be augmented by an older conception of leadership, first formulated by Aristotle as the 'great souled' individual and later termed 'magnanimity'. The meaning of magnanimous leadership, and its relevance for contemporary democratic transitions, is explored through an examination of the Australian founding, and in particular the leadership of Edmund Barton, who was instrumental in securing Australian federation.
\end{abstract}

Keywords: Edmund Barton, leadership, democracy, democratic transitions, magnanimity, honour, founding

\section{INTRODUCTION}

Nelson Mandela's decisive role in the transformation and founding of modern South Africa, the efforts of Aung San Suu Kyi in the democratic transition in Myanmar, and the importance of Corazon Aquino's democratic leadership in The Philippines, suggest that leaders can play an important role in initiating and sustaining democratic regime change. Yet the significance of leaders in the founding of democracies and their contribution to the democratisation and consolidation of regimes remains insufficiently understood or explored. The scholarship on democratisation has looked to economic, institutional or cultural factors in the democratisation process, paying less attention to the question of 'agency'. The leadership scholarship on the other hand has focused on the importance of leaders, but seems to have less to say regarding the type of leadership necessary for specifically democratic regime changes.

This article explores the importance of leaders and leadership in democratic regime change by arguing that democratic transitions, in addition to requiring leaders who possess the exceptional strategic and tactical leadership skills necessary for great political achievements, also need leaders of a specific moral disposition, with a profound sense of public service or duty, a willingness to sacrifice for a greater cause, a deep commitment to democratic ideals and a powerful ambition to secure a legacy as founders. This form of leadership, I will argue, is best captured by Aristotle's conception of the 'great souled' or what later came to be called 'magnanimous' leader, one who longs for great deeds and achievements requiring personal sacrifice that will be recognised and duly honoured when successful. Such an understanding of leadership, which augments the present

* Research for this article was supported by an Australian Prime Ministers Centre Fellowship, and an Australian Research Council Discovery Grant. 
scholarly distinctions between charismatic, transformative and transactional leaders, is especially important in democratic transitions because democracies need exceptional leaders who will undertake arduous tasks in founding the regime, yet in succeeding will not aggrandise themselves, deferring to the democratic principle of sovereignty of the people not only in the way they found the regime, but also in relinquishing office to allow the newly established institutions to gain stability and longevity.

To explain the nature of this form of leadership, and its efficacy in understanding democratic leadership in transition, I first examine Aristotle's conception of the 'great souled' leader within the larger context of the contemporary understanding of leadership. I then turn to the leadership of Edmund Barton, the democratic leader who was instrumental in federating the Australian colonies into the Commonwealth of Australia, subsequently becoming the first Prime Minister and later one of the first High Court judges. Barton and Australia are a useful case for our study of magnanimous leadership in democratic transitions for two related reasons. Barton's leadership is instructive because it does not readily fit into the charismatic or transformativetransactional models that dominate contemporary political leadership scholarship and therefore raises the question of whether we need a new theoretical approach to the study of foundational leaders in democracies. Australia is an important case to study because it is a successful transition that was both a founding - the Commonwealth of Australia was inaugurated on January 1,1901 - and to the extent that the previous colonies that federated were already informed by democratic principles, a democratic continuation. Accordingly, after briefly outlining Barton's life and achievements, I examine his character and career in detail to see if it may be better understood in terms of such magnanimous leadership. More specifically, I examine his great ambition and the sacrifices he incurs in pursuing federation, his sense of honour, and importantly, how his own conception of magnanimity is uniquely inflected through a democratic prism, evident especially in the need for public persuasion, integrity and compromise in such leadership. Barton's democratic magnanimity, requiring not only the skills of the innovator but also those of the mediator and conciliator, I contend, was significant for the Australian founding. In the concluding remarks I note the practical importance of magnanimity in directing democratic leaders to relinquish office and power after their work is accomplished.

\section{MAGNANIMOUS LEADERSHIP}

Modern scholarship on democratisation can be traced to the influential article by Rustow (1970), which argued that the factors that keep democracy stable may not be identical to those that brought it into existence. Subsequent research, which is extensive, has examined the conditions for both democratic transition and consolidation, focusing on institutional, economic and social factors that favour democratisation. Though the role of political leadership in democratisation is generally acknowledged, the often unique nature of leaders and the specific circumstances of their actions and resolutions have limited the extent to which broad or analytical insights and formulations can be drawn. ${ }^{1}$ For example, scholarship has tended to question the role of leadership as a precondition for democratisation (Bernhard 2006; Shin 1994); it has focused on

1. See, for example, Kane et al. (2008); Bunce (2000, p. 709); Diamond and Plattner (1996, p. 24); Linz (1990, p. 162). On the difficulties of theorising the role of leaders see Hollifield and Jillson (2000). 
the failure of leadership and how leaders have undermined democratisation rather than examining the significance of leadership success in such transformations (Linz and Stepan 1996; Diamond et al. 1990 cf. Grugel 2002); and importantly, the role of leaders has been analysed through the prism of elites, presuming that leadership and elite behaviour were identical (Higley 1992; Przeworski 1991 cf. Geddes 1999; O’Donnell and Schmitter 1986).

More promising is the recent scholarship on political leadership, shaped significantly by MacGregor Burns's influential book, Leadership (1978). Burns's (ibid., pp. 19, 20) distinction between 'transforming' leaders as 'moral leaders' who 'engage with others in such a way that leaders and followers raise one another to higher levels of motivation and morality' and 'transactional' leaders, those who take the initiative in making contact with others for the purpose of an exchange of valued things, has been especially influential not only in political leadership studies, but in the related fields of management and organisational theory. ${ }^{2}$ Burns's 'transformational' leader would therefore appear to be a useful starting point for understanding democratic leadership in transitions. Yet a core ambiguity regarding the significance of honour or 'esteem' for leadership ambition limits the efficacy of Burns's approach. Drawing on the psychological theories of Adler and Maslow, Burns recognises that esteem is important for leaders: 'the most potent sources of political motivation - the key elements of political ambition - are unfulfilled esteem needs (both self-esteem and esteem by others)' (ibid., p. 113, emphasis in original). But as the case of 'heroic' leadership (Burns's designation for Weber's 'charismatic' leadership) shows, such powerful needs can lead to mere self-gratification, rather than the 'quest for the kind of status and power that can be used to advance collective purposes that transcend the need and ambitions of individuals' (ibid., p. 106, emphasis in original). ${ }^{3}$ This inherent tension or ambiguity in the nature of esteem is especially important because of the significance of heroic leadership in democratic transitions. As Burns notes, '[h]eroic leadership plays a vital role in transitional or developing societies, where even the more idolatrous form of heroic leadership may meet the special needs of both leaders and followers' (ibid., p. 246). In such cases leaders may satisfy their powerful need for 'affection, esteem, and self-actualization' by satisfying the needs of followers including 'their need for esteem from performers who bestow recognition and flattery on them - and thus by their need for self-esteem' (ibid., p. 246). ${ }^{4}$ Burns rejects such 'idols' as inauthentic because, '[w]hile emotional needs in hero and spectator may be deeply involved, no central purpose, no collective intent other than short-run psychic dependency and gratification unites performer and spectator' (ibid., p. 248).

It is not clear, however, whether Burns's model of the 'transformative' leader can remedy this problem of inauthentic leadership that results from such psychic dependency. Maslow's 'self-actualising' individual, who wants to satisfy a hierarchy of needs that start with the physical, ascending to love, esteem and finally self-actualisation,

2. For a general overview, see Northouse (2010); Hunt (1999); Bass (1990); Tichy and Devanna (1990). On the question of the applicability of this dichotomy to organisational settings, see Pawar (2003); Gronn (1995, p. 18); Zaleznik (1977). On the difference between the two forms of leadership, see Bass (1985, p. 29), who argues there is no continuum, with transformative and transactional leadership at either extreme, but rather a variety of patterns, depending on different contexts.

3. For the scholarship on charisma generally, see Barbuto (1997); Bass (1985, p. 31).

4. Burns is especially concerned with appeals to 'base' instincts and the manipulators such as Joseph McCarthy (Burns 1978, pp. 458, 462). 
is used by Burns to explain how individuals can reconcile individual and collective aims (Burns 1978, p. 116). Yet he also realises that Maslow's emphasis on self-actualisation needs to be remedied to recognise 'mutual actualization with others'. Burns therefore corrects Maslow to argue that beyond self-actualisation, leaders have a capacity to learn and to be taught and therefore the ability to listen and be guided by others so that self-actualisation ultimately means the ability 'to lead by being led' (ibid., p. 117, emphasis in original). This perplexing formulation seeks to capture those cases where leaders 'rise with their followers, usually one step ahead of them, to respond to their transformed needs and thus to help followers move into self-actualization processes' so that in time the expression of needs becomes more related to socially sanctioned aims and collective goals and values, allowing leaders to 'help transform followers' needs into positive hopes and aspirations' (ibid., p. 117, emphasis in original). In correcting Maslow and Adler, Burns implicitly acknowledges the limitations of 'selfactualization' for understanding transformative leadership, especially in transitional or developing countries. As he notes, in emphasising the individual 'self', 'selfactualization' is insufficiently political. Yet in addressing this problem it is not evident whether Burns solves the larger question of how 'to lead by being led' provides a sufficient moral standard to distinguish a longing for recognition in excellence, virtue and public service from mere popularity or fame. Burns goes some way towards remedying the concept of self-actualisation for understanding political leadership, but in crucial respects seems to assert rather than explain and justify his claim that transformative leadership is moral leadership. ${ }^{5}$ I suggest that what Burns is actually looking for in his account of 'authentic' or 'moral' leadership, especially in democratic transitions, is what Aristotle called 'magnanimous leadership'. 6

Aristotle's concept of magnanimity has been the focus of recent leadership scholarship. Robert Faulkner (2007) in The Case for Greatness seeks to understand human excellence and truly great political ambition as evidenced in the actions of George Washington, Abraham Lincoln and Nelson Mandela by examining Aristotle's conception of the 'great souled' or magnanimous leader whose noble ambition is subordinated to the good of the country, contrasting this insight with the dangers of such ambition as evidenced in the works of Thucydides, Plato and Xenophon. Carson Holloway's (2008) edited collection, Magnanimity and Statesmanship, introduces and examines Aristotle's conception of magnanimity, allowing other contributors to explore changes in the concept in classical, Christian, and modern political thought. The final part of the volume consists of the study of political leaders, focusing on Thomas More, George Washington, Abraham Lincoln and Winston Churchill. Waller Newell's (2009) The Soul of the Leader, in a similar vein, examines the nature of leadership in the larger context of the American presidency and Athenian democracy. Central to the book is the significance of political ambition and honour in democracy, in particular an examination of how Lincoln displayed the virtues of Aristotle's 'great souled' man in abolishing slavery in America. Menaldo (2013), in Leadership and Transformative Ambition in International Relations, also relies on Aristotle and

5. On the ethical aspects of transformational leadership, see for example Brown and Treviño (2006); Price (2003); Turner et al. (2002); Deluga (2001).

6. Insights from psychology, though useful, do not seem to address this core question. See, for example, the 'new psychology of leadership' of Haslam et al. (2011), who see leaders as 'identity entrepreneurs' yet in doing so do not acknowledge the importance of dignity and honour as essential aspects of the leader-follower relationship. 
Machiavelli to understand the moral dimension of political ambition and the role of statesmanship, but his specific focus is foreign affairs. His concept of 'transformative ambition' allows him to trace the subtle connections between leadership ambition and regimes, as well as domestic and international politics. In addition to a reconsideration of Otto von Bismarck's leadership, Menaldo's close reading of Pericles's ambition shows how the Athenian statesman defined, elevated and thereby moderated Athenian imperialism. ${ }^{7}$ This necessarily brief overview of the scholarship indicates that Aristotle's concept of the 'great souled' individual may be an especially useful concept for understanding leadership in democratic transitions that will often require both the drive of ennobling ambition and a profound sense of public duty and sacrifice. It is therefore instructive to delineate the important features of Aristotle's formulation of the concept.

Aristotle defines the 'great souled' (megalopsychia) or magnanimous individual as 'one who deems himself worthy of great things and is worthy of them' (Nicomachean Ethics 1123b 3-5; Aristotle 2011). ${ }^{8}$ One of the most important great things for the magnanimous is honour because, according to Aristotle, it is what is given to the gods and conferred on the noblest people. The magnanimous therefore take pleasure in great honours, especially from serious human beings, and therefore they have complete contempt for honours from just anyone or for small honours or fame. Consequently they are also concerned in a measured way with fortune, wealth and political power, neither overjoyed with good fortune, nor deeply grieved with bad. They think wealth and political power are choice-worthy for the honour they confer (1124a 1-18). Because the magnanimous honour few things, they will hazard only great dangers and may even throw their life away for them. They will therefore be 'the sort to benefit others but be ashamed to receive benefaction' and are disposed 'to return a benefaction with a great one' (1124b 5-15). Accordingly, the magnanimous individual is neither servile nor boastful, and 'needs nothing, or scarcely anything, but to be eager to be of service, and to be great in the presence of people of worth and good fortune, but measured toward those of middling rank'. Yet in not respecting what is generally honoured, the magnanimous 'is idle and a procrastinator, except wherever either a great honour or a great deed is at stake; he is disposed to act in few affairs, namely, in great and notable ones' (1124b 25).

Aristotle's account of the magnanimous helps us understand the extraordinary and virtuous actions of certain individuals who are prepared to risk their welfare and sacrifice even their lives for the greatest or noblest public causes or matters of the highest public good. Yet in focusing on the crucial role honour plays in the motives and actions of such individuals, Aristotle reveals deep ambiguities in the nature of magnanimity. One important question concerns the self-sufficiency of honour and its relationship to virtue. The magnanimous is virtuous to the highest degree and therefore should be self-sufficient. But because honour seems to reside more with those who bestow it than with he who receives it, it seems to reveal a lack of self-sufficiency rather than goodness in the magnanimous (1095b 25-27). Moreover, the magnanimous is especially concerned with great honours, but it is not clear whether he seeks honours as proof of virtue, thus conceding the primacy of virtue, or as a

7. Especially useful is Menaldo's (2013, pp. 81-99) critique of the theoretical foundations of Burns's concept of the transformative leader.

8. On the magnanimous and the philosopher as the two major peaks of human excellence in the Ethics, see Tessitore (1996). On the character of classical and modern leadership, see Arnhart (1983). 
'prize' and reward of virtue, thereby conceding its superiority (1095b 28-29). ${ }^{9}$ The other question especially relevant for our discussion concerns the connection between magnanimity, statesmanship and the character of the political regime. Of particular relevance here is the extent to which the claims to outstanding virtue and therefore distinction can be accommodated in democratic regimes that emphasise the importance of popular sovereignty and therefore egalitarian honour. ${ }^{10}$ Lincoln's famous address to the Young Men's Lyceum of Springfield, Illinois, where he speaks of those of the 'family of the lion, or the tribe of the eagle' who in seeking distinction may threaten republican freedom is a clear and confronting articulation of these dangers (Lincoln 1943, emphasis in original). Yet, as Newell (2009, pp. 131-210) notes, Lincoln thought such magnanimity could be in the service of democracy, something he demonstrated in practice by repudiating slavery and defending the Union to bring forth 'a new birth of freedom'. ${ }^{11}$ These ambiguities help us understand the complex character of those individuals who will appear noble and heroic in sacrificing for the benefit of all, yet equally seem disdainful, contemptuous and needy, listless and neglectful of virtue when not moved by great matters of state.

\section{EDMUND BARTON}

To examine the efficacy of the concept of magnanimous leadership in democratic foundings and transitions I now turn to the leadership of Edmund Barton, founder of Australian federation and Australia's first prime minister. We should be clear that the intention is not to see whether Barton is magnanimous in Aristotle's sense of possessing all the virtues, which would require a comprehensive assessment of character, but rather to address the specific question of whether the concept of magnanimity yields important insights into his leadership and therefore the nature of leadership necessary in democratic transitions and foundings. We will therefore start with a brief and general overview of Barton's life and achievements. ${ }^{12}$

Edmund Barton was born on January 18, 1849, in Sydney, Australia, the youngest of a family of ten. Nicknamed 'Toby', he was educated at the University of Sydney,

9. On the core ambiguity of honour - that honour could not be sought for itself, which is love of mere fame - see Pangle (1999).

10. On the connection between magnanimity and statesmanship, and especially the importance of great offices (Eudemian Ethics 1232b 20-25) and prudence, see Holloway (2008, pp. 17-20). 11. On the importance of fame for the American founders, see McNamara (1999). On the possibility of such accommodation, see also Faulkner's (2007, pp. 194-197) reflections on Washington as 'patriot chief' who showed his commitment to the 'glorious cause' of republicanism in spite of humiliations and the 'false brilliant' of public opinion; and Menaldo's (2013, pp. 118-124) judgment of Charles de Gaulle as someone who combined personal ambition with the grandeur of France: 'he wanted to make his mark on the world, but it was through France and for it'. Foundings and major transitions may therefore be those exceptional instances where democracies especially need and can safely accommodate magnanimous leaders: see Kane and Patapan (2012, pp. 151-168).

12. The minimal scholarship on Barton is remarkable. The first biography was by Reynolds (1948), followed by a brief monograph (28 pages) by Rutledge (1974) and the second major biography by Bolton (2000), in time for the Centenary of Federation. The other works are few: an Australian Dictionary of Biography entry, a Senate lecture, and incidental or passing treatment in various books on Australian prime ministers and executive governments. 
where he excelled in Greek and Latin, winning a prize for classics, graduating with a BA with First Class Honors in Classics in 1868 and an MA in 1870. From 1868 he worked for a solicitor and was admitted to the New South Wales Bar in 1872. In 1877 he married Jane (Jeanie) Mason Ross, with whom he had six children. Barton was elected to a University of Sydney seat in the Legislative Assembly of New South Wales (NSW) in 1880 and was elected to the seat of East Sydney in 1882. From 1883 to 1886 he was the youngest Speaker of the Legislative Assembly, displaying 'quickness of perception, tact, courtesy and fairness' (Rutledge 1979, p. 4). It was in 1889 that he heard NSW Premier Sir Henry Parkes advocate federation of the Australian colonies, a cause he would take up for the next decade. He was a delegate to the Sydney Constitutional Convention in 1891, where he helped draft an early and influential version of the Constitution. Having failed to win his seat in the general election of 1894, he was reluctant to return to politics because, as he told Sir Henry Parkes, 'a return to active politics would be just now disastrous to the interests of my family' (cited in Rutledge 1979, p. 4). Though his finances were precarious for most of the 1890s he nevertheless devoted the next three years to tireless work for federation, including contributing to the newly organised Australasian Federation League by drafting a code of rules, giving advice and speaking at hundreds of meetings. By 1897, owing to his years of patient advocacy, he was the acknowledged leader of the federal movement in Australia and was elected to the Australasian Federal Convention that would draft the provisions of the Australian Constitution. At the first meeting of the Convention in Adelaide in March 1897 Barton was elected its leader and later chairman of the influential drafting and constitutional committees. The adjourned Convention met again in September in Sydney to consider the amendments proposed by colonial legislatures and reconvened in Melbourne on January 20, 1898, finally rising on March 17, 1898. In March 1900 Barton led the Australian delegation to London to explain its terms and to press for its passage through the British Parliament without amendment. In December 1900 Barton was commissioned to form a ministry and became the first Prime Minister of the new Commonwealth of Australia that was proclaimed on January 1, 1901. He contested and won his new seat in the first federal elections in 1901, as did all his ministers, and he remained Prime Minister until 1903, when he resigned and became the senior puisne judge of the newly established High Court of Australia. He served on the Bench for seventeen years, and died suddenly of heart failure on January 7, 1920.

This very brief biography of Barton shows the extraordinary range of his achievements, above all his significant, arguably essential contribution to the creation of the new Commonwealth of Australia. In the scholarship on political leadership he would be understood as a 'transformational' leader. Yet, as we will see, his character and manner, though distinct and impressive, is less of the heroic, radical or charismatic visionary and more of the accommodating conciliator who will seek reasonable compromise and consensus through persuasion rather than an intransigent insistence on a unique vision. He is a moral leader with integrity who is prepared to sacrifice for a greater cause, yet one cannot readily say that he transforms the character of his followers. Barton and the Australian founding therefore provide an important case study for understanding the nature of leadership in democratic transitions, but more specifically for understanding a type of moral leadership that combines ambition and sacrifice, transformative and transactional leadership, an idea best captured in Aristotle's 'great souled' leader and what later came to be known as 'magnanimity'. 


\section{BARTON AND MAGNANIMOUS LEADERSHIP}

Aristotle's insight into the soul or character of the magnanimous reveals someone who longs for great deeds and actions and is willing to endure great hardship for these endeavours. Such an individual is concerned with the highest honours but will attempt to be worthy of them, rather than seek them out. These powerful longings will determine how the magnanimous order their lives, how they will rank their duties and obligations and, importantly, how they treat others around them. I will argue that Aristotle's conception of magnanimity accounts for important aspects of Barton's character and his actions as leader. Of course it is possible to argue a stronger claim that Barton, as an outstanding scholar of the classics, sought to emulate the Greek ideal of the 'gentleman', the 'kalos kai agathos' ('noble' and the 'good') or the Aristotelian model of the exceptional leader. ${ }^{13}$ We know that his education and interest in the classics stayed with him throughout his life, ${ }^{14}$ arguably shaping his character and his understanding of public duty. ${ }^{15}$ Without deciding this question conclusively, I suggest that magnanimity accounts for Barton's form of leadership, and explains specific aspects of his actions that we will examine in some detail, such as his commitment to a great cause, his conception of honour, and the seemingly contradictory aspects of his character that evinced both prodigious hard work and love of indolence and luxury.

\subsection{Great tasks}

Magnanimous leadership accounts for the central place of federation as the 'great cause' in Barton's life and career. It explains in large measure the direction it took, the sacrifices it mandated, and the rewards it yielded in reputation and office. The magnanimous, according to Aristotle, seek 'great' deeds. Barton, I would argue, was looking for such a great deed but did not seem to find it in the academy, even though he excelled in his undergraduate studies and completed his masters. The law was another possibility, but he initially took it up because he was not independently wealthy and

13. As a classics scholar, Barton was familiar with Plato and Aristotle. In his second year at the University of Sydney he studied with Charles Badham, the newly appointed professor of classics from Oxford. Badham had edited several works of Plato and was 'particularly renowned as a textual critic skilled at identifying the original words and intentions of ancient writers' (Bolton 2000, p. 10).

14. We find, for example, that he carried with him Herodotus's Histories, which he read, translated and glossed during his term as Prime Minister (see Barton Papers, Personal Documents, National Library of Australia, http://nla.gov.au/nla.ms-ms51-3-959a, accessed May 5, 2014). We also know that in 1901, some 35 years after leaving university, he was sufficiently fluent in Latin to converse with Pope Pius X in Latin on his Papal Audience (Reynolds 1948, p. 183). Note also that Barton's confidential telegram conversation with Sir Samuel Griffith in 1903 regarding the Chief Justiceship of the new High Court was conducted in Latin for reasons of confidentiality (Bolton 2000, p. 297).

15. This argument would suggest that Barton as well as a generation of classics-educated students in the foremost English public schools as well as Oxford and Cambridge would have known, and perhaps been influenced by, such a classical education that included Plato and Aristotle. On the nature of this education, see generally Armitage (2000) and Turner (1981); and in terms of specific leaders, see for example the influence of the classical view on Gladstone (Isba 2006); and Churchill (Toye 2008). 
needed a steady income to get married and raise a family. ${ }^{16}$ Though ultimately successful, becoming a Queen's Counsel at an early age, it would seem that he often neglected his legal practice for public service. He certainly did not pursue a business or mercantile career; indeed, as we will see, there was ambivalence in his regard for wealth that is typical of the magnanimous - showing contempt for it, yet realising that honour by itself was not sufficient to maintain his increasingly large family and responsibilities to his siblings. ${ }^{17}$ This left politics, and public life, as the suitable stage for his ambitions, and indeed, as we have noted, he did seek political office from an early age, first as a member of parliament representing Sydney University, then as Speaker in the New South Wales Legislative Assembly. These offices were no doubt onerous and instructed the young Barton on important aspects of colonial and parliamentary politics. Yet there seems to have been something missing from them, evident in his decision to seek election to the New South Wales Legislative Council, the Upper House where he was not a regular attendee, and his general reluctance to take up Cabinet posts and other offers of ministerial responsibility. All this seemed to change, however, when Barton read Sir Henry Parkes's 1889 Tenterfield speech advocating federation of the colonies. Barton wrote to Parkes endorsing those views and a few days later, on November 3, 1889, at the Australian Natives Association meeting at Sydney Town Hall, publicly declared his support for federation. As the first prominent member of the protectionist Opposition to support the free-trade Premier he was widely criticised, though Parkes praised his 'manly and able speech' (cited in Reynolds 1948, p. 78).

From this point on, Barton seemed to have found his calling. Between 1890 and the First National Australasian Convention in Sydney in 1891, Barton collaborates with Parkes, intensively studies federal constitutions and along with Griffith and Kingston, helps draft the Constitution on board the Queensland government yacht Lucinda. By this stage Barton was committed to federalism, as we can see from a New South Wales House of Assembly speech in 1891 where he declares: 'There is one great thing which ranks above all others in my political life, and will actuate me until it is accomplished and this is the question of the union of the Australian colonies'. He told several of his friends, according to Reynolds (1948, p. 84), '[m]y bristles are all up over the question of Federation'. He informally accepts the mantle of leadership of the federal movement from Parkes in 1891 and this role is never questioned in the remaining nine years of the movement.

Barton's view of federation and his commitment to it is evident from his public statements. Responding to B.R. Wise, a free-trader who had questioned Barton's motives in advocating a non-political Australasian Federation League, Barton wrote a lengthy letter on June 30, 1883, published in The Sydney Morning Herald, where he states:

There are men who cannot realise that one may set a great cause so high, may reverence it so deeply, as to be incapable of turning it to any purpose lower than that of its consummation. (Cited in Reynolds 1948, p. 95, emphasis added)

16. See, in particular, his early correspondence with Jeanie where he notes his poverty and lack of prospects (Bolton 2000, pp. 17-18).

17. Bolton's (2000) biography of Barton outlines in detail his financial circumstances, especially the financial sacrifices his family endured due to Barton's dedication to the federal cause. For example, in 1889, Barton's financial situation was so dire that close friends raised over $\$ 1400$ for his family without his knowledge (Bolton 2000, pp. 202-203). 
Barton had in federation his 'great cause' that merited his hard work in public speaking, letter writing and general advocacy, in the contribution to the Constitutional Conventions, especially his leadership and management of the debates as well as the detailed committee work drafting the Constitution, and finally the subsequent involvement in the referenda endorsing its provisions, all of which culminated in his election as Australia's first Prime Minister. Great tasks and ambitions moved him, allowing him to disdain or neglect what he thought were the smaller things. But their successful accomplishment also meant that he had to redefine the demands of duty.

Barton's actions as Prime Minister after federation are explicable in terms of the magnanimous who has achieved his great ambition but still has duties to fulfil. From this perspective, the goal of his ambition is never prime ministership as such, but federation. This explains his time in office, with his early years characterised by a seeming lack of commitment and energy, a sense that he did not have his heart in it. His greater application after his visit to England for the Coronation of King Edward VII in 1902 and later Imperial Conference may be explained by the numerous honours and awards he receives, making him realise the greatness of the office he has been instrumental in creating. His decision to retire as prime minister and become a justice of the High Court was not taken easily, because he seemed to rank the judicial office below the political - 'can I persuade myself to leave politics and take second place?' (cited in Bolton 2000, p. 297, emphasis in original) - and because he was excited by the prospect for new policy on Imperial trade. 'Can I leave the field just when the trumpets are calling?' was his question to Lord Tennyson, South Australia Governor, who advised, '[y]ou can do equally patriotic work as judge of the High Court' (cited in Bolton 2000, pp. 297-298, emphasis in original). In addition to his sense of public duty, he may have been influenced in his decision by other concerns, including his health and providing for his family who had paid such a high price for his ambition. ${ }^{18}$

That magnanimity explains important aspects of Barton's leadership is confirmed by the judgment of his contemporaries. Barton, according to Sir Robert Garran, was the 'devoted knight-errant of Australian union', neglecting worldly considerations for his cause (cited in Bolton 2000, p. 119). When he retired as Prime Minister, the Acting Leader of the Opposition, Sir William McMillan stated: 'Although we have always been politically opposed, there was one characteristic of Sir Edmund Barton which I recognized, and that was his generous nature and his extreme magnanimity' (cited in Reynolds 1948, p. 189). Or, as the Commonwealth Minister for External Affairs, Patrick McMahon Glynn, put it on Barton's death on January 7, 1920, 'Sir Edmund Barton was one of those men who happily seem to be created for great occasions' (cited in Reynolds 1948, p. 197).

\subsection{Great honours}

Magnanimity also accounts for Barton's approach to honour, which in turn shapes his political life. As we have seen from Aristotle's account of the 'great souled', there is a core ambiguity in the magnanimous person's disposition towards honour, seeking the greatest of honours while realising there is something questionable about such an

18. A number of factors may have influenced his decision. The High Court position allowed a pension. Though his new health regime had given him greater vigour, his collapse in his Parliament House office in August 1903 and his physician's advice that to increase his 'expectation of life' he should 'relinquish or diminish' the 'excessive amount of strain which at present bears upon you' may also have played a part in his decision (cited in Reynolds 1948, p. 187). 
ambition. Moreover, because the magnanimous are concerned with meriting great honour they are fearful of mere fame, and are especially concerned with not appearing to be honour-seekers. These tensions are evident in Barton's life and explain major decisions that affected his career.

Barton is concerned with his reputation. He was generally regarded as generous, equable and reasonable, rarely inclined to extreme passions. Yet the few instances where we see Barton intemperate and very angry concern challenges to his probity and reputation. ${ }^{19}$ Importantly, if great honour in a sense drives Barton, it also limits what he does. The 'great' cause of federation and the great honour it will bestow explains why Barton is willing to sacrifice his health and personal wealth. For example, in July 1899, Barton explains to Walter James that he is unable to visit Western Australia because he is 'a poor man, made much poorer by sacrifices in this long struggle: sacrifices which were necessary, I admit, since no great cause succeeds unless someone at least is ready to lose all his own so that his country gains a great end' (cited in James et al. 1949, pp. 57-58). Great deeds and honours also explain why he declines those 'lesser honours' that either do not compare with the highest goal, or indeed may jeopardise it. ${ }^{20}$

Yet the ambiguous place of honour for the great souled individual also had important and potentially costly political consequences. Deakin (1944, pp. 31-32), in his character sketch of Barton in the 1891 Convention, notes that he "had a fine public spirit and a high sense of personal honour, he was it might be said too superior to his surroundings to be able to achieve success'. Some years later the same point was made in The Freemans Journal (September 8, 1900):

Amongst his many commanding qualities, he has one or two commanding defects of temperament. These defects were obvious in recent New South Wales history, and paradoxically as it may appear, they have been of the highest service to the cause of Federation. It requires a great question to arouse his interest. When his interest is aroused he fights with superhuman energy, sacrificing fortune, profession, home life, leisure - everything. But when the victory is won, he is careless of spoils. When the gates are battered in, and the flag of the citadel is hauled down, he has a tendency to allow the camp followers to enter and take the loot. ${ }^{21}$

Here the author nicely summarises the character of the magnanimous leader and, as I will argue, presciently anticipates what has famously come to be known as the 'Hopetoun Blunder'. The blunder refers to the decision by Lord Hopetoun, recently appointed Governor-General, to commission the Premier of New South Wales, Sir William Lyne, an ardent anti-Federalist, to become acting Prime Minister instead of Barton before elections in 1901. It seems that Hopetoun's general unfamiliarity with Australian circumstances, his small circle of advisors, especially Leader of Opposition Reid who may have wanted the office himself, his ill health and Lyne's generous hospitality and attentiveness on his arrival, may account for his decision. Yet correspondence from Deakin to Barton reveals a complex and swiftly moving series of events. Lyne's appointment and his attempts to recruit a sufficiently strong Cabinet were

19. Consider, for example, Barton's role as counsel in the Proudfoot case and the allegations of conflict of interest when he was Attorney General (Bolton 2000, p. 119; Reynolds 1948, p. 126). 20. At different times Barton turns down the position of leader of opposition, Cabinet posts, a Supreme Court judgeship, as well as Knighthoods (in 1887, 1891 and 1899).

21. The Freemans Journal, Supplement, 8 September 1900, p. 8. http://trove.nla.gov.au/ndp/del/ page/12419992?zoomLevel=1, accessed 17 September 2015. See also the newspaper cuttings by Littleton Groom in the Australian National Library, MS 1452, boxes 1-3. 
initially greeted with disbelief and frustration by Deakin, Forrest and others, shifting to a resigned acceptance of Lyne as Prime Minister and commiseration with Barton, who is advised to accept it as another act of public service, to the ultimate result where Lyne is unable to form a sufficiently credible cabinet due to the unwillingness of Deakin and others to serve, with Lyne returning his commission to the Governor, who then appoints Barton (see generally Bolton 2000, pp. 218-222; Reynolds 1948, pp. 163-170). We do not have all the correspondence in this instance, especially Barton's letters, but from Deakin's letters we get the sense that Barton's view of merited honour restrains him from taking an active role in advancing his cause, using O'Connor as his intermediary. Barton's magnanimity and fine sense of honour does not ultimately deprive him of the Prime Ministership, though largely due to the generosity of his friends and his popularity. He is less successful, however, in his ambitions to be the Chief Justice of the Australian High Court.

On stepping down from the Prime Ministership in 1903, Barton accepted a position on the newly created Australian High Court, joining Sir Samuel Griffith and Sir Adrian Knox. He was certainly qualified for the position, due to his professional standing as a Queen's Counsel and as one of the authors of the Constitution, yet he deferred the Chief Justiceship to Sir Samuel Griffith, whom he regarded as the foremost legal mind in Australia. When in 1919 Griffith retired due to ill health, Barton wished to succeed him as Chief Justice and all his colleagues agreed he had the best claim to the office. But he never indicated this view to anyone, perhaps because his sense of honour suggested such a request would seem presumptuous and he hoped others would offer it to him. When he finally did, it was too late, Cabinet having decided on Sir Adrian Knox. When advised, Barton took the news 'with the calm that always distinguishes him' according to the Governor General Sir Ronald Munro Ferguson (cited in Bolton 2000, p. 333).

\subsection{Schole and indolence}

Magnanimous leadership also explains a genuine curiosity, if not a contradiction, in Barton's character. On the one hand we have Barton as the notorious 'toss-pot Toby' popularised by the Bulletin Magazine and newspapers, the indolent who loves conversation, good food and fine drink too much, even at the expense of his health. Alfred Deakin, a close colleague and later Prime Minister appeared to endorse this view: 'At no time and in no sense intemperate, his genial, affectionate nature made him so companionable that he spent many hours in his club chair which would have been more profitably spent in his chambers or in his study' (Deakin 1944, pp. 31-32).

Yet we also have Robert Garran's account of how Barton, O'Connor, Downer and he worked day and night on the drafting of the Constitution at the Melbourne Convention, with Barton and Garran the last ones carrying on till four or five in the morning when Garran would finally 'persuade him to call it a day' (Bolton 2000, p. 167). There are many other examples attesting to Barton's willingness to undertake exceptionally demanding work. He spends months in 1890 reading extensively on federations for the forthcoming 1891 Convention. His contribution to that Convention, especially to the drafting Committee on board the Queensland government steamship Lucinda, where the first and influential draft of the Constitution was drafted, is acknowledged by Sir Samuel Griffith, who noted that 'Mr Barton ... devoted himself to that work as strenuously and industriously as any man with whom I have ever had the pleasure of working, and I venture to say that I have done a good deal of hard work in my time' (cited in Bolton 2000, p. 80). His unflagging work for federation, in the form of letter writing, speeches and formation of the Australasian Federation Leagues, 
with over 1000 speeches in New South Wales and more than 3000 in general was impressive. Furthermore, his leadership of the 1898 Constitutional Conventions, the campaign in support for the 'Yes' referenda in New South Wales and the demanding schedule of his personal election for a seat in the first federal parliament show the consistency of his commitment. The demands on the new prime minister and his diligence as High Court judge are continuing evidence of this aspect of his character.

How, then, can we reconcile the 'Toss-pot' and the prodigious worker? Aristotle's magnanimity may provide the means for doing so. ${ }^{22}$ The magnanimous, according to Aristotle, will act in great and notable affairs, but because he does not respect what is generally honoured he otherwise is 'idle and a procrastinator' (1124b 25). Federalism, as we have seen, was the great cause that moved Barton sufficiently to extract from him extreme endeavour, hard work and sacrifice. In the Adelaide Convention Barton noted:

It is a labour of love to me to do anything in my power to help forward the consummation of the union of Australia. I do not know what my temperament may be in other respects, but I think I always find that the harder the work is, in connection with this subject, the more ready I am to undertake it. There is a stimulus in a movement of this kind which is mostly absent from other public movements. (Cited in Bolton 2000, pp. 161-162)

When the New South Wales constitutional referendum finally succeeded in 1899 , Barton's measured comment ably summed up his feelings: 'I have expended both my energies and my fortune in the cause of the union and ... I reap my reward in this glorious victory' (cited in Bolton 2000, p. 198).

But when not occupied in the federal cause, Barton would become 'idle', favouring schole or virtuous leisure that could too readily lapse into excess. Schole or leisure, according to the classical understanding, was needed to pursue a higher political and philosophical life and therefore required sufficient means to ensure freedom from necessity, especially work. Barton, I suggest, would have known of this idea of schole from his classical education. His life showed how he elevated schole above labour or work. An omnivorous reader, according to his son, '[h] would read anything rather than nothing' (cited in Reynolds 1948, p. 48). He enjoyed the theatre, especially Shakespeare and opera, and appreciated music and art. He especially loved witty conversation, and was a regular at the Athenaeum Club, which became an intellectual hub, with visits by international authors, scholars and artists. ${ }^{23}$ He was a fellow of the Sydney University Senate and a trustee of the Public Library of New South Wales. These virtuous aspects of Barton's schole of course could equally shift to excess, revealing the lazy idler, the glutton and the immoderate. Hence the many stories of his prodigious capacity to eat and drink, his fastidiousness with both, and his willingness to talk to almost anyone. ${ }^{24}$ These excesses affected his health so that he was often advised to adopt a strict diet limiting food and drink. It also

22. An alternative explanation for Barton's variable temperament has been provided by Dr David Barton, his medically qualified grandson, who thought Barton suffered a bipolar disorder (see Bolton 2000, p. 59).

23. To become a member, you needed literary, artistic or scientific qualifications. International visitors included Mark Twain and Robert Louis Stevenson. On the founders of the club, see Bolton (2000, pp. 29-30); Reynolds (1948, pp. 51-52).

24. See, for example, the account by W.J. Taylor, a lawyer visiting Barton who was recuperating from a broken ankle. Taylor found the regime too much for him, according to Bolton (2000, p. 58). 
occasionally affected his public duties. An amusing example may suffice: travelling to Melbourne by rail to join the mail steamer that would ultimately take him to London for discussions on the passage of the Constitution, Barton was so engrossed in a conversation in the Moss Vale dining room that the train left without him, requiring him to ride on the footplate of the next engine sent to get him (Bolton 2000, p. 205).

\section{BARTON AS DEMOCRATIC LEADER}

In Coriolanus (see especially Act II, Sc 2; Act III, Sc 1) Shakespeare presents us with an able leader who, due to his excessive pride, cannot hide his contempt for the plebs, and is in turn rejected by them. As Aristotle suggested and Shakespeare dramatically shows, those inclined to magnanimity may also be prone to boastfulness and may therefore not always be well disposed to democracy. Yet, as we have seen, the Australian founding was above all democratic. Moreover, as an unusual combination of a radical new beginning and a preservation and continuation of democratic traditions, it required the abilities of an innovator and conciliator-negotiator. Indeed, we may say that all democratic foundings and transitions will require for their success magnanimous leaders who are also democratic leaders, open to the democratic requirements of public discussion and deliberation. If true, then it is arguable that Barton, because of his reasonable and accommodating character and his commitment to democratic accountability, was essential for the success of the Australian founding. Let us briefly review both of these aspects of his leadership to see the extent to which it contributed to the success of Australian federation.

Barton's contemporaries testify to his good nature, to his reasonableness and equanimity, his disposition to reconcile disparate positions and seek productive compromise. He had, according to Reynolds (1948, p. 50), 'that pleasing faculty of drawing people out of themselves and making them feel they had a sympathetic hearer', an attitude which 'sprang from founts of tolerance and kindliness' according to Barton's close friend Albert Piddington. Use of reasoning, persuasion and negotiation to achieve a successful (but not always preferred) outcome displays itself throughout his career. He develops and hones these skills in his role as Speaker in the New South Wales Legislative Chamber, and deploys them in the course of the 18981899 federation conventions where as leader of the Convention he emphasises in his inaugural speech the importance of being open-minded and willing to discuss in the spirit of compromise. His general view at the Convention is that '[t]he real way out of the difficulty is conciliation, conference, and common sense' (cited in Bolton 2000, p. 148). His actions during the Convention prove to be crucial for its success. Most famously, realising the debate has reached an impasse at a crucial point, he adjourns due to a 'bronchial cold', allowing overnight negotiations that on resumption of the Convention next day, resolve the stand-off between conflicting parties (Bolton 2000, p. 151; Reynolds 1948, p. 115). At the first meeting of the Second Australasian National Convention in Adelaide in 1897 Barton as leader of the Convention gives, in the opinion of Wise, one of his greatest speeches advocating the need for 'reasonable compromise' (Reynolds 1948, p. 112). Later, at the Melbourne Session, Barton outlines his own approach: 'I have endeavoured often to stand between conflicting parties, and to lead the Convention to a decision which is just between those parties, and that is my attitude now' (cited in Reynolds 1948, p. 113).

This ability to seek reasonable agreement, consensus and compromise becomes essential in his role as the first Prime Minister. On assuming office in 1901 his 
colleagues were some of the most able and experienced colonial political leaders, hence his Cabinet is variously described as a 'Cabinet of Kings', 'an army of generals' and an 'orchestra of conductors' (Reynolds 1948, p. 176). In addition he depended on Labor members for a majority in the House of Representatives and had the minority in the Senate, forcing him to 'somehow contrive a different majority for almost each piece of legislation', which included important provisions on immigration, industrial conciliation and arbitration, the establishment of the High Court and the public service (see generally Weller 2007, pp. 20-32). He also had the difficult task of asserting the new authority of the Commonwealth, against the claims of the new states and with dealings with Colonial office. Finally, these abilities were manifest in his role as High Court judge, where he displayed clarity of thought and argumentation, especially in crucial cases concerning the nature of Australian federalism. In addition to his ability to compromise and conciliate, what is especially revealing about Barton is his democratic inclination to hear the views of others. Many people comment on his ability to listen and learn from conversations with people from all walks of life. This inclination is so pronounced that for some it was a fault in his character. Atlee Hunt, an admirer, noted that 'Barton's love of talk and his unwillingness to hurt anyone's feelings by abruptly terminating a conversation were the means of using up a lot of time' (cited in Reynolds 1948, p. 259).

In his support for democracy, Barton occupied and advocated a middle course, between the conservatives who wanted Imperial Federation with Britain and the radical democrats advocating an Australian republic. There would be a new nation, but important colonial traditions and rules would still remain, including responsible government and ties with Britain. In this he was perhaps influenced by his Australian origins - he was born in New South Wales and was therefore a 'native'. Self-government and Australian nationalism were therefore both important political causes for Barton. Barton's democratic commitment is especially evident in his recognition of the political importance of the 'people'. At a people's Convention at Bathurst in November 1896 Barton rejected the Federal Council as fatally flawed because it was not popularly elected, and therefore insisted that no scheme of federation should be adopted unless approved by the Australian people (Bolton 2000, p. 138). In his speech before the Second Australasian National Convention in Adelaide (March 22, 1897) Barton refers to the 'force of public opinion, as expressed by the press, by public men, and the by the Parliament', noting that, 'without success gained under the influence of public opinion there cannot be a successful Federation, because Federation must depend on the goodwill of the people'. Federation therefore depends on the 'forces of public opinion' which he considers 'irresistible because it is the people who govern these colonies' (cited in Reynolds 1948, p. 111). Later, at the 1897 Melbourne Session of the Convention, Barton endorses retaining 'Commonwealth of Australia' in the Constitution, in place of 'United States of Australia' because 'Commonwealth is the greatest and most stately name by which a great association of self-governing people can be characterised' (cited in Reynolds 1948, p. 114). His endorsement of popular sovereignty is evident in his revealing question at the end of a session: 'Is this a constitution which will enable a free people to come together to work out their own destiny?' (cited in Bolton 2000, p. 167).

Barton's democratic sensibility is especially evident in his adoption of democratic means in pursuing constitutional change. He evidently thinks the general public needed to be informed and persuaded before any major change could or should be implemented. That is why he devotes so much time and effort in giving speeches, in writing letters and in developing political organisations to establish federation. 
He relies extensively on speeches and speechmaking throughout his entire career. Many of these speeches are of course given at official public events. But many are also given at public gatherings organised by various associations. These speeches, which we should recall were at the time reproduced in full in newspapers and read widely, proved to be influential in shaping public opinion in the course of Australian federation. But Barton did not simply rely on public persuasion. He also turned to political organisations, establishing the Australian Federation Leagues to achieve his goals. ${ }^{25}$ Even in London, negotiating the terms of the new Constitution, he and his fellow delegates deploy popular means, especially the use of society functions and the press, to influence British imperial opinion to ensure the safe passage of the Constitution. 'Barton is a great favourite here' is the opinion of several prominent people, resulting in a significant victory over secretary of state Joseph Chamberlain, who sought to change important parts of the Constitution (Reynolds 1948, p. 159). But above all it is in the drafting and adoption of the Constitution that we see Barton's commitment to democratic processes. The requirement of colonial parliaments to enact 'Enabling Acts' consenting to the draft terms to be discussed in the public fora of the Constitutional Conventions, where delegates are again popularly elected, and finally the use of referenda for the public endorsement of the Constitution, show the importance of the 'people' in the political process and underline the democratic nature of the Australian founding.

The discussion above shows that Barton's sense of public service coexisted with an enduring commitment to popular sovereignty and democratic processes. This aspect of his leadership would not be complete without noting the type of democracy that was secured by the Australian founding. One of the first measures enacted by the new Commonwealth parliament was a series of laws banning non-European immigration and repatriating Pacific Island workers who had been employed in the Queensland cane fields. ${ }^{26}$ Because there was widespread support for these policies, what was at issue in enacting these measures was not the principle itself, but the way the provisions would be framed. Most Labor members and some of Barton's own followers wanted a ban on Asians, Africans and Pacific Islanders, while Barton, sensitive to Colonial Office concerns of not offending the Japanese (who were negotiating the Anglo-Japanese Alliance), sought to moderate this approach by advocating a version of the legislation used in the South African colony of Natal, which required prospective immigrants to undertake a dictation test of 50 words in any European language (Bolton 2000, pp. 243-250). Barton's proposal succeeded and these laws became the foundation of the 'White Australia Policy' that would endure until the final vestiges were removed in the 1970 s. ${ }^{27}$

In important respects these enactments were no more than a continuation of wellestablished colonial doctrine and policy since the 1840s restricting non-European immigration and in particular Chinese immigrants working in gold mines. In 1896

25. Starting with two major speeches in Corowa and Albury in December 1892, he is instrumental in establishing the Australian Federation Leagues, with branches in all the colonies, with the intention of organising and educating the public about federalism. Barton uses the League as a platform for promoting federalism, speaking at meetings in New South Wales before all types of audiences (Reynolds 1948, p. 97).

26. The Commonwealth Immigration and Restriction Act 1901, the Pacific Island Labourers Act 1901, and the Commonwealth Franchise Act 1902. For a general overview of Australian immigration policy, see Tavan (2005); Jupp (2002); London (1970); Palfreeman (1967); Willard (1967).

27. On the gradual dismantling of the policy, see Tavan (2005). 
Imperial authorities, concerned with diplomatic sensitivities regarding China, India and Japan, had reserved royal assent to Bills passed by several colonies prohibiting outright the immigration of Asians, Africans and Polynesians. The overall intention of these measures was to pre-empt those economic and social problems it was thought would ensue from unchecked immigration. In its positive formulation, according to Tavan (2005, p. 19), it was a 'morally imbued affirmation of the type of society Australians wanted to build: white, British-Australian as well as cohesive, conformist, liberal-democratic and egalitarian' ${ }^{28}$ Defended on the bases of Social Darwinism and racial determinism theories that justified racial homogeneity, and social-liberal views endorsing cultural homogeneity, these ideas were buttressed by a newly emerging sense of nationalism and the fear that large-scale Chinese immigration would undermine working and living conditions of Australian workers. That Barton endorsed these views, modifying them only to the extent that it accommodated Imperial concerns, indicates the nature of his vision for Australia: his ambition was not a founding of an altogether new Australia, but rather the federation of colonies, preserving as much as possible the British legacy of responsible government and the common law. Even if he had wished to challenge these views, it is unlikely he would have succeeded. 'No motive power', according to Deakin, 'operated more universally on this Continent, or in the beautiful island of Tasmania, and certainly no motive power operated more powerfully in dissolving the technical and arbitrary political divisions which previously separated us than the desire that we should be one people, and remain one people, without the admixture of other races' (cited in Willard 1967, p. 119). These policies therefore show the extent to which Barton was both a transformative and transactional leader and the specific conception of democracy that informed the Australia founding.

\section{MAGNANIMITY AND DEMOCRATIC FOUNDINGS}

We have paid close attention to Edmund Barton's character and actions to see if the concept of magnanimity allowed us greater insights into his leadership and thereby what is needed in the founding of democracies. Our study of Barton suggests that the concept of magnanimity can augment the leadership scholarship, by showing the need for both transformational and transactional leadership in foundings, as well as the unique combination of personal ambition and public service required for successful transitions. In terms of democratic regime change, magnanimity highlights the importance of pursuing democratic means for the democratic transitions, including public persuasion, deliberation, agreement and consensus. Above all, it shows the moral complexity of such democratic leadership that defers to the principle of popular sovereignty while confronting the core question of who constitutes 'the people'.

In these concluding remarks I return to Barton to suggest that one aspect of magnanimity - the possibility that such leaders will leave office willingly - may prove to be even more important in ensuring the continuing stability of newly established democracies. If the magnanimous are concerned with honour, then Barton was richly

28. As Tavan notes, this view assumed the equality of citizens, rather than a universalistic equality of all. As J.C. Watson, Leader of the Labor Party, put it in 1901: 'We never say that "all men are equal" ... But we say that every man should be equal with every other man in the eyes of the law, and that equal opportunities should be afforded so far as the law can allow every citizen' (cited in Tavan 2005, p. 19). 
rewarded for his leadership of the federal movement. In addition to being the first Prime Minister and one of the three inaugural High Court justices, Barton as 'Australia's Noblest Son' was recognised internationally with a number of honorary degrees, awards and distinctions. ${ }^{29}$ Yet a 2001 publicity campaign celebrating the Centenary of Australia's Federation conceded that few knew or recalled the name of Australia's first Prime Minister. ${ }^{30}$ History seemed to have left Barton behind. The historian Geoffrey Bolton, the author of the second major Barton biography, traced this neglect of Barton to the influence of historians, who for various reasons had chosen not to celebrate and memorialise his achievements. ${ }^{31}$ Bolton's assessment is persuasive, though perhaps we should add another important factor for Barton's neglect, one that goes to the heart of our discussion regarding the nature of leadership required in democratic transitions.

We have seen how a specific aspect of Barton's magnanimity was a form of selfdeprecation or modesty, evident in a disinclination to assert himself or to claim great honours. In the latter part of his life this manifested itself in a reluctance to record his achievements for posterity. Unlike other founders such as Deakin, Wise and Garran, Barton never wrote an autobiography or an account of federation. ${ }^{32}$ Nor did he seem to seek out a Boswell or Eckermann to spare his modesty while recording his achievements for posterity. Indeed, he and Jeanie had destroyed a number of his personal or private documents in moving house in 1909 (Bolton 2000, p. 312). Consequently, it is some time after his death that we have the first extended assessment of his achievements. ${ }^{33}$ The neglect of Barton, therefore, is due not only to the disputes between historians, but in some measure can be traced to Barton himself and his view of his legacy. Perhaps democratic foundings need such leaders who do not wish to assert their continuing and potentially countervailing authority through autobiography and biography. Leaders who willingly leave office or do not wish to burden the future with indelible memories of their achievements may be essential for the future stability and prosperity of democratic regimes. If so, Barton's reticence may well be his final and most generous legacy as a magnanimous democratic leader.

29. These included an honorary LLD from the University of Cambridge, honorary DCL from the University of Oxford, an honorary bencher of Gray's Inn, freedom of the City of Edinburgh, a Japanese Order of the Rising Sun (first class), a Knighthood (CGMG), membership of the Privy Council, and a Medallion from the Pope.

30. 'Ask Your Mother'. TV commercial for Australia's Centenary of Federation. Advertising Agency GREY Advertising, Canberra; Brave Films, directed by Amanda Jane. Available at: http://www.youtube.com/watch?v=6niKTWMx4_c, accessed September 17, 2015.

31. According to Bolton (2000, pp. 340-347) these reasons included: the disproportionate influence of Deakin's view of Barton, which became influential with Walter Murdoch's Alfred Deakin: A Sketch (1923) and later Deakin's own The Federal Story (1944); the Melbourne-Sydney rivalry of historical studies; and the radical-nationalist tradition that saw the founding as conservative, evident for example in the work of L.F. Crisp.

32. His archives and correspondence were lodged in the Australian National Library in 1929 (Bolton 2000, p. 340). The Barton Papers, MS 51, can now be accessed online at: http://nla.gov. $\mathrm{au} /$ nla.ms-ms51.

33. As we noted, there are few works on Barton, with the first biography by Reynolds appearing in 1948. Contrast this with Deakin, Australia's second Prime Minister, who wrote extensively and on last count had twenty books examining his life and achievements. 


\section{REFERENCES}

Aristotle (2011), Aristotle's Nicomachean Ethics, translation by R.C. Bartlett and S.D. Collins, Chicago: University of Chicago Press.

Armitage, D. (2000), The Ideological Origins of the British Empire, Cambridge, UK: Cambridge University Press.

Arnhart, L. (1983), 'Statesmanship as Magnanimity: Classical, Christian and Modern', Polity, 16, 263-283.

Barbuto, J. (1997), 'Taking the Charisma Out of Transformational Leadership', Journal of Social Behaviour and Personality, 12, 689-697.

Bass, B. (1985), Leadership and Performance Beyond Expectations, New York: The Free Press.

Bass, B. (1990), Bass and Stogdill's Handbook on Leadership: Theory, Research and Managerial Implications, New York: The Free Press.

Bernhard, M. (2006), 'Charismatic Leadership and Democratization: A Weberian Perspective', Central and Eastern Europe Working Paper Series, no 43.

Bolton, G.C. (2000), Edmund Barton, Sydney: Allen \& Unwin.

Brown, M.E. and L.K. Treviño (2006), 'Ethical Leadership: A Review and Future Directions', The Leadership Quarterly, 17 (6), 595-616.

Bunce, V. (2000), 'Comparative Democratization: Big and Bounded Genralizations', Comparative Political Studies, 33 (6/7), 703-734.

Burns, J.M. (1978), Leadership, New York: Harper Colophon Books.

Deakin, A. (1944), The Federal Story: The Inner History of the Federal Cause, 1880-1900, Melbourne: Robertson and Mullins.

Deluga, R.J. (2001), 'American Presidential Machiavellianism: Implications for Charismatic Leadership and Rated Performance', The Leadership Quarterly, 12 (3), 339-363.

Diamond, L. and M. Plattner (1996), The Global Resurgence of Democracy, Baltimore, MD: Johns Hopkins University Press.

Diamond, L., J. Linz and S. Lipset (1990), Politics in Developing Countries: Comparing Experiences with Democracy, Boulder, CO: Lynne Rienner.

Faulkner, R. (2007), The Case for Greatness: Honourable Ambition and its Critics, New Haven, CT: Yale University Press.

Geddes, B. (1999), 'What Do We Know About Democratization After Twenty Years?', Annual Review of Political Science, 2 (1), 115-144.

Gronn, P. (1995), 'Greatness Re-visited: The Current Obsession with Transformational Leadership', Leading \& Managing, 1 (1), 14-27.

Grugel, J. (2002), Democratization: A Critical Introduction, Basingstoke, UK: Palgrave Macmillan.

Haslam, A.S., S.D. Reicher and M.J. Platow (2011), The New Psychology of Leadership: Idenitity, Influence and Power, New York: Psychology Press.

Higley, J.G.R. (1992), Elites and Democratic Consolidation in Latin America and Southern Europe, Cambridge, UK: Cambridge University Press.

Hollifield, J.F. and C.C. Jillson (2000), Pathways to Democracy: The Political Economy of Democratic Transitions, New York: Routledge.

Holloway, C. (ed.) (2008), Magnanimity and Statesmanship, Lanham, MD: Lexington Books.

Hunt, J. (1999), 'Transformational/Charismatic Leadership's Transformation of the Field: An Historical Essay', Leadership Quarterly, 10 (2), 129-144.

Isba, A. (2006), Gladstone and Dante: Victorian Statesman, Medieval Poet, Royal Historical Society, Woodbridge, UK: Boydell \& Brewer.

James, W., A. Deakin, E. Barton, A.J. Peacock, J. Forrest, B.R. Wise, J.W. Hackett and H. Briggs (1949), 'The James Papers - Letters on Federation', The Australian Quarterly, 21 (4), 55-63.

Jupp, J. (2002), From White Australia to Woomera, Cambridge, UK: Cambridge University Press.

Kane, J. and H. Patapan (2012), The Democratic Leader: How Democracy Defines, Empowers and Limits its Leaders, Oxford: Oxford University Press. 
Kane, J., H. Patapan and B. Wong (eds) (2008), Dissident Democrats: The Challenge of Democratic Leadership in Asia, New York: Palgrave Macmillan.

Lincoln, A. (1943), ‘Address Before the Young Men's Lyceum at Springfield, Illinois, January 27, 1838', in T.H. Williams (ed.), Selected Writings and Speeches of Abraham Lincoln, New York: Hendricks House.

Linz, J. (1990), 'Transitions to Democracy', The Washington Quarterly, 13 (3), 143-164.

Linz, J. and A. Stepan (1996), Problems of Democratic Transition and Consolidation: Southern Europe, South America, and Post-Communist Europe, Baltimore, MD: Johns Hopkins University Press.

London, H.I. (1970), Non-White Immigration and the 'White Australia' Policy, Sydney: Sydney University Press.

McNamara, P. (ed.) (1999), The Noblest Minds: Fame, Honor, and the American Founding, Lanham, MD: Rowman \& Littlefield.

Menaldo, M.A. (2013), Leadership and Transformative Ambition in International Relations, Cheltenham, UK and Northampton, MA: Edward Elgar.

Murdoch, Walter (1923), Alfred Deakin: A Sketch, London: Constable.

Newell, W.R. (2009), The Soul of the Leader, New York: HarperCollins.

Northouse, P. (2010), 'Introduction', in Leadership: Theory and Practice, Thousand Oaks, CA: Sage, pp. 1-14.

O'Donnell, G. and P. Schmitter (1986), Transitions from Authoritarian Rule: Tentative Conclusions about Uncertain Democracies, Baltimore, MD: Johns Hopkins University Press.

Palfreeman, A.C. (1967), The Administration of the White Australia Policy, Melbourne: Melbourne University Press.

Pangle, T.L. (1999), 'The Classical and Modern Liberal Understandings of Honor', in P. McNamara (ed.), The Noblest Minds: Fame, Honor, and the American Founding, Lanham, MD: Rowman \& Littlefield, pp. 207-220.

Pawar, B.S. (2003), 'Central Conceptual Issues in Transformational Leadership Research', Leadership \& Organization Development Journal, 24 (7), 397-406.

Price, T.L. (2003), 'The Ethics of Authentic Transformational Leadership', The Leadership Quarterly, 14 (1), 67-81.

Przeworski, A. (1991), Democracy and the Market: Political and Economic Reforms in Eastern Europe and Latin America, Cambridge, UK: Cambridge University Press.

Reynolds, J. (1948), Edmund Barton, Sydney: Angus \& Robertson.

Rustow, D. (1970), 'Transitions to Democracy: Towards a Dynamic Model', Comparative Politics, 2 (3), 337-363.

Rutledge, M. (1974), Edmund Barton, Melbourne: Oxford University Press.

Rutledge, M. (1979), 'Barton, Sir Edmund (Toby) (1849-1920)', Australian Dictionary of Biography, National Centre of Biography, Australian National University, published in hardcopy 1979, available at: http://adb.anu.edu.au/biography/barton-sir-edmund-toby-71, accessed online May 5, 2014.

Shin, D. (1994), 'On the Third Wave of Democratization: A Synthesis and Evaluation of Recent Theory and Research', World Politics, 47 (1), 135-170.

Tavan, G. (2005), The Long, Slow Death of White Australia, Carlton North: Scribe Publications.

Tessitore, A. (1996), Reading Aristotle's Ethics: Virtue, Rhetoric, and Political Philosophy, New York: SUNY Press.

Tichy, N. and M. Devanna (1990), The Transformational Leader, New York: Wiley.

Toye, R. (2008), Lloyd George and Churchill: Rivals for Greatness, London: Pan Macmillan.

Turner, F.M. (1981), The Greek Heritage in Victorian Britain, New Haven, CT: Yale University Press.

Turner, N., J. Barling, O. Epitropaki, V. Butcher and C. Milner (2002), 'Transformational Leadership and Moral Reasoning', Journal of Applied Psychology, 87 (2), 304-311.

Willard, M. (1967), History of the White Australia Policy to 1920, Melbourne: Melbourne University Press.

Zaleznik, A. (1977), 'Managers and Leaders: Are They Different?', Harvard Business Review, 55 (3), 67-78. 